\title{
DEMYSTIFYING A HERMENEUTIC APPROACH TO IS RESEARCH
}

\author{
Phyl Webb \\ School of Information Systems \\ University of Tasmania \\ Private Bag 87, Hobart 7001, Australia \\ Email: webbp@utas.edu.au \\ Carol Pollard \\ CIS Department, John A. Walker College of Business \\ Appalachian State University, Raley Hall \\ Boone, NC 28607, USA \\ Email: pollardce@appstate.edu
}

\begin{abstract}
While hermeneutics is firmly embedded in social science research and has proven merit as a qualitative research philosophy and data analysis technique, the majority of IS researchers continue to be hermeneutic neophytes. This paper seeks to promote and demystify this valuable but challenging tool, exploring the evolution of hermeneutics and its different approaches, presenting a brief overview of previous IS hermeneutic research, as reported in the literature and describing the applicability of hermeneutics to qualitative IS research In illustration, and in an attempt to smooth the way for other novice ìhermeneutsî, it presents the choice and application of one hermeneutic approach based on the work of Ricoeur and Gadamer, in a research in progress. The paper concludes with a reflection on the value of the hermeneutic approach that was adopted in the research process and its contribution to IS research.
\end{abstract}

\section{INTRODUCTION}

While some IS researchers have embraced the use of hermeneutics, to many it still remains a complex, mysterious approach. In the following sections, the authors attempt to describe the challenges they encountered on the way to gaining enlightenment as ìhermeneutsî by describing their application of one approach to a research in progress. The results of using the hermeneutic approach are also discussed together with suggestions to guide those researchers who may choose to use a similar strategy in their research.

Hermeneutics is by nature interpretivist. It deals with the interpretation and understanding of text, including text analogues (Myers and Avison, 2002).

Many hermeneutic scholars have extended their conception of text to include not just the documentary artefacts that human subjects create, but also their individual actions, group behaviours, and even social institutions, all of which, as text analogues, have meanings that can be read and interpreted (Lee 1994, p149)

This suggests that hermeneutics is an approach that lends itself to application within organisational contexts where there is commonly, a preponderance of documentation describing and explaining the organisationís focus, mission, processes and procedures. In addition, the employees themselves represent a rich and valuable source of text or text analogue, most commonly in the form of 
interview transcripts. To some, hermeneutics is more than a data analysis technique or method. It can instead be treated as both an underlying philosophy and specific mode of analysis (Myers and Avison 2002). Common to all forms of hermeneutics is the concept of the hermeneutic circle or spiral. This concept encapsulates the idea that, in an attempt to understand the true meaning of something, one seeks a pre-existing understanding of the article under study from oneís own experience. This, in turn, enhances and expands knowledge and understanding of the article and leads to greater understanding (Mallery, Hurwitz and Duffy 1987). To gain perspective on hermeneutic research, Table 1 provides a brief chronology of its prominent scholars.

\begin{tabular}{|l|l|}
\hline Scholar & Lived \\
\hline Friedrich Daniel Ernst Schleiermacher & $1768-1834$ \\
\hline Wilhelm Dilthey & $1833-1911$ \\
\hline Martin Heidegger & $1889-1976$ \\
\hline Hans-Georg Gadamer & $1900-2002$ \\
\hline Jurgen Habermas & $1929-$ \\
\hline Paul Ricoeur & $1913-2005$ \\
\hline
\end{tabular}

Table 1 - Prominent Hermeneutic Scholars: A Chronology

Hermeneutics has been described in a number of ways. Mallery et al (1987) include the following classification in their informative discussion of hermeneutics:

- Classical Methodological Hermeneutics

- Philosophical Hermeneutics

- Critical Hermeneutics

- Phenomenological Hermeneutics

These categories are a useful starting point for beginning to understand hermeneutics. This paper contains a brief discussion of the proponents of hermeneutics most commonly encountered in IS research framed within the categories provided above. This is followed by a brief overview of published IS research that applies a hermeneutic approach and an explanation of the application of hermeneutics in an ongoing IT governance research project.

\section{CLASSICAL METHODOLOGICAL HERMENEUTICS}

Hermeneutics originated as the study and interpretation of literary and biblical texts. The Greek scholars who undertook the study of texts analysed and interpreted works for consistency in grammar and literary style. Biblical scholars applied similar methods. However they also made use of allegory in their interpretation and application of hermeneutics (Mallery et al 1987).

According to Bleicher (1980), Schleiermacher, an early and important contributor to the development of classical methodological hermeneutics, maintained that the purpose of hermeneutics was to derive understanding from the text under study. In this way, Schleiermacher began to develop a philosophical focus for hermeneutics. He did this through his consideration of the process of understanding and the conditions that are necessary for a valid interpretation (Bleicher 1980). In recognising this need for a more consistent systematic approach to hermeneutic study Schleiermacher made a valuable contribution to the evolution of hermeneutics. He also initiated increased interest in examining the epistemological issues of interpretation and understanding, (Mallery et al 1987). 
Bleicher (1980) writes on Schleiermacher: ì Given adequate historical and linguistic knowledge, the interpreter is in a position to understand the author better than he understood himselfî (p15) and credits him with developing a ì systematic hermeneuticsî compromised of two interpretations:

1. Grammatical

2. Psychological

Schleiermacher provided forty-four canons to explain grammatical interpretation (Bleicher 1980). The first two are considered most important. In summary, these encapsulate a view that:

1. In order to comprehend or understand the text one needs to understand the linguistic context of the text.

2. In order to understand an individual part of the text the surrounding words, within which the part under study is situated, also need to be considered.

Schleiermacher also developed canons for psychological interpretation with the intention of exploring the ëcreative inner processí (Dilthey 1976).

In his writing about Schleiermacher, Dilthey (1976) describes the aim of the hermeneutic process as one that allows an understanding of ì the author better than he has understood himself: a proposition which is the necessary consequence of the doctrine of unconscious creationî (p116). This view of Schleiermacher is also supported by Gadamer (1976).

Following Schleiermacher came Dilthey, a key figure in the development of hermeneutics who emphasised the role of understanding (Verstehn) who contrasted it with the pre-Kantian, Cartesian practices of explanation (Erklarung) (Hamilton 1994, p64). Dilthey spent much time studying Schleiermacherís work and was heavily influenced by him and is often grouped with Schleiermacher as a romanticist.

Diltheyís approach to hermeneutics differs from Schleiermacherís in this movement between understanding and explanation as two key foci. ì Explainingî refers to the provision of a general description of the type, providing its key characteristics. ì Understandingî infers a more in-depth knowledge of the individual internal characteristics and intentions of a member of the type (Olson and Carlisle, 2001). This movement from inner to outer was summarised epistemologically by Bleicher (1980) who proposed that ìgenerally valid knowledge can be derived both from appearances and inner experienceî ( p22).

Dilthey is credited with having developed a methodological hermeneutics but was also criticised for his ì backslidingî into objectivism. He ascribed to a belief that the interpreter could understand the authorís intentions through a process called re-living, which effectively results in the conclusion that there is one true account, or objectification (Bleicher 1980). Diltheyís heremeneutics advocates acceptance of the text at face value without any critical consideration or review. In this way it differs from some of the more contemporary hermeneuts (Myers, 1994). Modern day hermeneutics is indebted to both Schleiermacher and Dilthey for their important contributions to the advancement of the concept of hermeneutics.

\section{PHILOSOPHICAL HERMENEUTICS}

Heidegger has been described as the ìmain proponentî of dialectical hermeneutics (Mallery et al 1987). This is an approach that heralded a new philosophy for hermeneutics. His work had an ontological leaning that sought to illuminate not just the method of understanding but also the nature 
of being. ì Heidegger moves hermeneutics from a theory of interpretation to a theory of existential understandingî (Mallery et al 1987, p5).

Heidegger saw three fore-structures of understanding (Bleicher 1980):

1. Fore-having, already owning knowledge of the system, context or situation within which the phenomenon under study exists. This is a broad general view (Demetrio 2001).

2. Fore-sight, this level is specific to the phenomenon being studied but is still at a general level (Demetrio 2001) and

3. Fore-grasping, the detailed understanding of the phenomenon under study (Demetrio 2001)

Heideggerís intention in outlining fore-structures is made clearer by Grondin (1994):

Ö in order to interpret a text, for example, it is necessary to make our ownì Iì

situation transparent so that we can appreciate precisely the otherness and alterity of the text $\tilde{n}$ that is, without allowing our unelucidated prejudices to dominate the text unwittingly and so conceal what is proper to it (p97).

His view of the importance and necessity for fore-structures represents a radical change in thinking regarding the hermeneutic circle.

Gadamer, a student of Heidegger, built on Heideggerís thinking in developing philosophical hermeneutics (Fleming et al 2003) and suggests that this approach represents movement away from the view of the subjectivity or objectivity of the circle. In fact, Gadamer suggests, the circle, ì describes understanding as the interplay of the movement of tradition and the movement of the interpreterî (Gadamer 1976, p120). He contends that an individualís current experience and learning contribute to their ability and means of understanding (Mallery et al 1987).

Similarly, Gadamer rejected objectivism as a delusion of human thought. He argued that there is and can be no such thing as objectivism since all human understanding is influenced subjectively (Gadamer 1976, Bleicher 1980). In essence, Gadamerís hermeneutics is not a method (Prasad 2002, Fleming et al 2003), but rather a way of life. He viewed hermeneutics as going beyond a mere methodological approach and rather occurring as a pervasive universality (Grondin 1994).

Gadamer on the other hand, differed from Heidegger in his belief that experience of other cultures and manners of thinking can moderate the effects of oneís own prejudices by providing a contrasting view. He saw language as the key to unlocking the interpreter to other cultural view points and as a consequence language becomes the key to understanding that ì does not scientifically reconstruct a speakerís intention, but instead mediates between the interpreterís immediate horizon and his emerging oneî (Mallery et al 1987, p6)

\section{CRITICAL HERMENEUTICS}

Habermas is a critical theorist. His aim is to see beyond the interpretation of the text to the provision of a critique of the textís ideological makeup (Prasad 2002). This view has resulted in critical theorists entering into debate with philosophical hermeneuts, such as Gadamer, with a view to increasing the critical focus of the practice of hermeneutics (Prasad 2002). Habermas (1968) and the Habermas/Gadamer debate can be briefly summarised in the following three points:

1. Effects of fore-structure \& understanding (Bleicher 1980). Habermas contests these are not ëgivení and always legitimate, but rather can be built through self-reflection (Prasad 2002). 
2. The status of language (Bleicher 1980). Habermas (1968) was in agreement with Gadamer regarding the relationship of language to understanding and interpretation, and the fundamental nature of language as a foundation for social institutions. However, he does not accept that language is ontological as Gadamer believes but rather that it is subject to alteration by social movements (Prasad 2002).

3. The justifiability of taking a critical position (Bleicher 1980). Gadamer contended that it is not possible for a truly critical position to be taken from within the culture under study, and that as previously stated, the development of a narrow method should not be the goal of hermeneutics but rather to enable understanding (Prasad 2002).

\section{PHENOMENOLOGICAL HERMENEUTICS}

Ricouer emphasises the complementary nature of the work of Gadamer (1976) and Habermas. Rather than being opposed, Ricouer contends that they are both necessary and can comfortably coexist (Mallery et al 1986, Prasad 2002). This view is best summarised by Ricouer himself:

The consequence for hermeneutics is important: we can no longer oppose hermeneutics and the critique of ideology. The critique of ideology is the necessary detour which self-understanding must take, if the latter is to be formed by the matter of the text and not by the prejudices of the reader (Ricouer 1981, p144).

In addition to Ricoeurís work that draws together the arguments of Gadamer and Habermas, his Theory of Interpretation attempted to reconcile Diltheyís dichotomy of understanding and explanation (Mallery et al 1986, Scott-Baumann 2003). Ricouer made a notable contribution to hermeneutics through his attempts to acknowledge, understand and, where appropriate, reconcile the apparently diverse positions of several other prominent hermeneutic scholars (Bleicher 1980). Ricoeurís view of hermeneutics incorporates both philosophy, as represented by ontology and epistemology (Bleicher 1980) while his theory of interpretation provides a more general practical approach to derive meaning from text although it cannot be described as a method (Wiklund, Lindhulm and Lindstrom 2002). Ricoeurís notion of the text is any discourse that is captured in writing. He does not, as some authors claim, see everything as text. He does, however, argue there are similarities between human action and text and for this reason they can be understood in similar ways (Langdridge 2004).

Ricoeur sees the text as the objectification of the participantís subjectivities. The discourse represents the participantís view of their world and once objectified in this way, can be interpreted by others in light of its own inherent meaning. The intention of the originator of the discourse is of less consequence than the meaning that emerges directly from the text (Leonardo 2003). Ricoeur (1981) offers the following insights:

Hermeneutics can be defined no longer as an inquiry into the psychological intentions which are hidden beneath the text, but rather as the explication of the being-in-the-world displayed by the text. What is to be interpreted in the text is the proposed world which I could inhabit and in which I could project my ownmost possibilities (p112).

This brief discussion of some prominent hermeneutic scholars and their work provides an overview of the evolution of hermeneutics over time. There are many more prominent and influential hermeneutic scholars than have been included here; however those listed provide a representative cross-section of the hermeneutic tradition and its historical development. More importantly, the 
scholars described here are the proponents whose approaches are most commonly discussed in IS research. The use of hermeneutics in IS research is discussed next.

\section{HERMENEUTICS IN INFORMATION SYSTEMS RESEARCH}

Hermeneutics has been adopted and applied in many disciplines including nursing, education, anthropology and information systems (Myers 1995). The application of hermeneutics in information systems has an ever-expanding list of proponents. Among the earliest of these is Boland (1985) who recognised the appropriateness of hermeneutics and the related area of phenomenology for research in the IS area:

Information systems are data becoming information in consciousness; organizations are socially constructed through language, and our reasoning about both these processes takes place in dialogue (Boland 1985, p181).

Hermeneutics has been used in information systems for a variety of different purposes, Table 2 provides an overview of hermeneutic IS research, its research focus and the hermeneutic approach adopted. It should be noted that the table is not complete but merely representative; authors such as Boland, Lee and Myers have published more than has been cited here. In addition there will, undoubtedly, be other IS researchers who have used hermeneutics and are not included in this list. It can be seen from the table that a critical approach to hermeneutics has been favoured by IS researchers and, given the practical orientation of the discipline, this seems an appropriate choice.

It is interesting, however, to note that Gadamer features so prominently in the IS critical hermeneutic discussion, given that he saw his work conflicting with the work of hermeneuts such as Habermas (1968), who are commonly categorised as critical. Gadamer did, however, acknowledge a need for critical self-consciousness (Mallery et al 1987). Ricouer (1981) identified that the views of Gadamer and Habermas were actually mutually compatible and the inclusion of Ricouerís work does help to mediate the distance between Gadamer and the practice of critical hermeneutics. The following section discusses the choice and application of a hermeneutic approach adopted in an ongoing IT governance project by way of illustration.

\section{THE RESEARCH SETTING}

One Australian large organisation was the focus of this case study, since it was felt that large organisations are more likely to have formal IT governance processes. The reason for limiting this research to within one geographical and national boundary was to eliminate differences in national culture in IT (Robbins and Stylianou 2002, Kim and Peterson 2003), corporate governance mechanism and country-specific regulatory frameworks (Charkham 1995) from the research situation.

Limiting the study to one organisation provided an opportunity for the researcher to become deeply immersed in the research situation. Controlling the research in this way helped to reduce any potential resistance to the research from within the organisation that may have occurred where there was a perception that issues of commercial sensitivity or security may be compromised by a detailed cross-organisational study. 


\begin{tabular}{|c|c|c|}
\hline Research Topic & Citation & Hermeneutic Approach \\
\hline \multirow[t]{2}{*}{$\begin{array}{l}\text { Systems } \\
\text { Development }\end{array}$} & $\begin{array}{l}\text { Butler, T. (1998), "Towards a hermeneutic method for interpretive research in information } \\
\text { systems", Journal of Information Technology, Vol. 13, pp. 285-300. }\end{array}$ & $\begin{array}{l}\text { Phenomenological hermeneutics (derived from Heidegger and } \\
\text { Gadamer) }\end{array}$ \\
\hline & $\begin{array}{l}\text { Butler, T. (2003), "An institutional perspective on developing and implementing intranet - } \\
\text { and internet- based information systems", Information Systems Journal, Vol. 13, pp. } \\
\text { 209-231. }\end{array}$ & $\begin{array}{l}\text { Phenomenological hermeneutics (derived from Heidegger and } \\
\text { Gadamer) }\end{array}$ \\
\hline \multirow[t]{3}{*}{ Implementation } & $\begin{array}{l}\text { Bussen, W. and Myers, M. D. (1997), "Executive information systems failure: a New } \\
\text { Zealand case study", Journal of Information Technology, Vol. 12, pp. 145-153. }\end{array}$ & Critical hermeneutics (derived from Myers) \\
\hline & $\begin{array}{l}\text { Myers, M. D. (1994), "A Disaster for Everyone to See: An Interpretive Analysis of a } \\
\text { Failed IS Project", Accounting, Management \& Information, Vol. 4, No. 4, pp. 185- } \\
201 .\end{array}$ & $\begin{array}{l}\text { Critical or Dialectical hermeneutics (derived from Gadamer \& } \\
\text { Ricoeur) }\end{array}$ \\
\hline & $\begin{array}{l}\text { Myers, M. E. (1995), "Dialectical Hermeneutics: A Theoretical Framework for the } \\
\text { Implementation of Information Systems", Information Systems Journal, Vol. 5, No. 1, } \\
\text { pp. 51-70. }\end{array}$ & $\begin{array}{l}\text { Critical or Dialectical hermeneutics (derived from Gadamer \& } \\
\text { Ricoeur) }\end{array}$ \\
\hline $\begin{array}{l}\text { Communication } \\
\text { Richness }\end{array}$ & $\begin{array}{l}\text { Lee, A. S. (1994). "Electronic Mail as a Medium for Rich Communication: An Empirical } \\
\text { Investigation Using Hermeneutic Interpretation." MIS Quarterly Vol. } 18 \text { No. 2, pp. 143- } \\
157 .\end{array}$ & Hermeneutics (derived from Ricouer) \\
\hline Evaluation & $\begin{array}{l}\text { Sheffield, Jim (2005). "The Evaluation of GSS-Enabled Interventions: A Habermasian } \\
\text { Perspective” in Proceedings of the } \mathbf{3 8}^{\text {th }} \text { Hawaii International Conference on System } \\
\text { Sciences (Ed Sprague R H), Big Island, Hawaii. }\end{array}$ & Phenomenological (derived from Habermas) \\
\hline \multirow[t]{3}{*}{ Methodological } & $\begin{array}{l}\text { Boland Jr, R. (1985). “Phenomenology: A Preferred Approach to Research on Information } \\
\text { Systems”. Research Methods in Information Systems. E. Mumford, R. Hirscheim, G. } \\
\text { Fitzgerald and T. Wood-Harper. New York, North-Holland: pp193-201. }\end{array}$ & Hermeneutics (derived from Gadamer) \\
\hline & $\begin{array}{l}\text { Boland Jr, R. J. (1991). "Information Systems Use as a Hermeneutic Process". In } \\
\text { Information_Systems Research: Contemporary Approaches \& Emergent Traditions. } \\
\text { H.-E. Nissen, H. K. Klein and R. Hirscheim. Amsterdam, North-Holland: 439-464. }\end{array}$ & Hermeneutics (discussed with Ricoeur, Pepper \& Rorty) \\
\hline & $\begin{array}{l}\text { Lukaitis, S. and Cybulski, J. (2004), "A Hermeneutic Analysis of the Denver International } \\
\text { Airport Baggage Handling System", in Proceedings of the Information Systems } \\
\text { Foundations Workshop: Constructing and Criticising, (Eds, Hart, D. N. and Gregor, S. } \\
\text { D.) Australian National University, Canberra. }\end{array}$ & Critical hermeneutic (derived from Gadamer \& Kidder) \\
\hline Philosophical & $\begin{array}{l}\text { Myers, M.D. (2004). "Hermeneutics in Information Systems Research”, in Social Theory } \\
\text { and Philosophy for Information Systems, Mingers, J. \& Willcocks, L. Chichester, West } \\
\text { Sussex. John Wiley, pp 103-128 }\end{array}$ & Critical hermeneutic (derived from Gadamer and Ricoeur) \\
\hline
\end{tabular}

Table 2 Hermeneutics in IS Research 
The organisation that participated in this research has in excess of 100,000 employees, distributed across approximately 1000 sites throughout Australia. The organisation operates in the retail industry sector. The research reported focussed on the organisationís largest division consisting of more than 700 sites across the country. The IT unit supporting this division employs in excess of 600 staff.

Data were gathered from semi-structured interviews and organisational artefacts e.g. company documents. The data were collected during two stages, six months apart. In addition to using the rigorous approach of hermeneutics to analyse the data, the collection of multiple data types within this research, collected at different times, from different participants enabled triangulation of the data to occur (Denzin 1970, MacDonald and Tipton 1993), thus increasing the likelihood of a more accurate representation of the phenomenon under study. Twenty-five nominated individuals from different levels, different units and sub-units and from both business and IT within the organisation were invited to participate in face-toñface interviews, to discuss their perceptions and views of how IT governance worked in theory and practice with the subject organisation.

Each participant was interviewed in the first phase of data collection. In order to ensure a more complete picture of the organisational reality, the interviewees were drawn from senior IT management, IT staff, senior business managers and business staff. This cross section of roles was selected in part, because of the recognised ëgap between IT and the rest of the business that exists in many organisations (Peppard 2001), and in part because of the nature of IT governance, which as a sub-set of corporate governance is not just a matter for the IT area but is very much an issue for business units and the entire organisation.

The second stage of data collection was conducted in order to explore, test and add detail and richness to the insights generated from the first round of data collection. The three participants selected for this round represented areas within the organisation included in the study, i.e. one from business, one from IT and one who served in a checking or monitoring role. Recent and long term employees were interviewed in Round Two. The second round of data collection was completed by telephone. In all, 28 interviews were conducted over the two stages of the data collection.

\section{CHOOSING AND APPLYING A HERMENEUTIC APPROACH}

The research in progress that is the focus of this paper adopts an interpretivist approach to explore the prescribed versus practiced IT governance and the attendant consequences of the differences between theory and praxis in a large organisation in Australia. Data was collected through two rounds of semi-structured interviews conducted with employees who were involved in IT governance at various levels and in various departments throughout the organisation and through analysis of company documents. The research seeks to answer the following research questions:

1. What is the nature of IT governance?

a) As expressed by management (prescribed) and

b) As it occurs in the actual manifestation of (practiced) IT governance within the organisation

2. How do the differences between theory and praxis manifest themselves within the organisation?

3. What are the consequences of the differences between theory and praxis to the organisation?

The use of hermeneutics was first considered since it has been suggested that hermeneutics is a recognised framework for the analysis of organisations (Bryman 1989). In addition, Frost et al 
(1985) elaborate that it is particularly useful when looking at organisational culture and others have applied it to the analysis of socio-technical interactions (Barley 1986, Harvey and Myers 2002). The hermeneutic approach was adopted in this research as being most appropriate because of its suitability to the conduct of research within socio-technical and organisational contexts.

Moreover the epistemology applied in this research is interpretivist constructivism and draws heavily from hermeneutics. In addition, within the interpretivist epistemology, a hermeneutic approach was considered the most appropriate choice for this research supporting as it does the construction of understanding from the analysis and interpretation of the data under study. Dilthey considered:

Ö the central difficulty of all interpretative skill. The whole of a work must be understood from the individual words and their combinations, and yet the full comprehension of the details presupposes the understanding of the whole (Dilthey 1976, p115).

Given that a number of hermeneutic approaches have been adopted in IS research, the next challenge was to consider the different points of view. After much consideration, an approach informed by both Ricoeur (1981) and Gadamer (1976) was adopted for the following reasons.

1. It was felt that the hermeneutics advocated by Ricoeur offered richness for the study and interpretation of complex social situations such as those investigated in this study in that it draws together the work and thoughts of prominent hermeneutic scholars and reconciles the two foci of understanding and explanation, the specific and the general.

2. Ricoeurís focus on the text as the vehicle of meaning, whilst balancing this against a need for critical analysis and judgement, supported the selection of a hermeneutic approach inspired by his work.

3. Gadamer contributed his recognition of the need for awareness of prejudices, his view of the importance of questions, and his concept of horizon and fusion of horizons.

A diagrammatic representation of the research philosophy and design appears in Figure 1. Ricoeurís concepts of distanciation, appropriation, understanding, explanation and the application of a critically self reflexive and questioning approach were used to inform this research in progress. These concepts are discussed next.

Distanciation, also referred to as historicality by Myers (1994), refers to the distance between the text and its origins. Distance from a text can exist as a consequence of temporal, cultural, or lingual factors, due to the intention of the author to deceive or mislead the interpreter or due to changing social practices (Lukaitis and Cybulski 2004). Ricoeur sees that the starting point of any interpretation should be the text. Ricoeurís concept of distanciation differs from the ëtemporal distanceí of Gadamer through the movement to a text focus (Langdridge 2004). In Ricouerís words:

For the distanciation revealed by writing is already present in discourse itself, which contains the seeds of the distanciation of the said from the saying, to follow Hegelís famous analysis at the beginning of The Phenomenology of Mind: the saying vanishes, but the said persists (Ricoeur 1981, p92)

Ricouer also encourages the interpreter to distance themselves from their own prejudices and preconceived understandings and also from their reading of the text. He advocates a ëcritique of prejudiceí in order that the interpreter may proceed through the analysis and interpretation in a self critical and self-reflexive manner (Langdridge 2004).

Distanciation from oneself demands that the appropriation of the proposed worlds offered by the text passes through the disappropriation of the self. The critique of 
false consciousness can thus become an integral part of hermeneutics, conferring upon the critique of ideology that meta-hermeneutical dimension Habermas assigns to it (Ricouer 1981, p94-95).

The process of interpretation thus becomes a dialectic between distanciation and appropriation (Geanellos 2000).

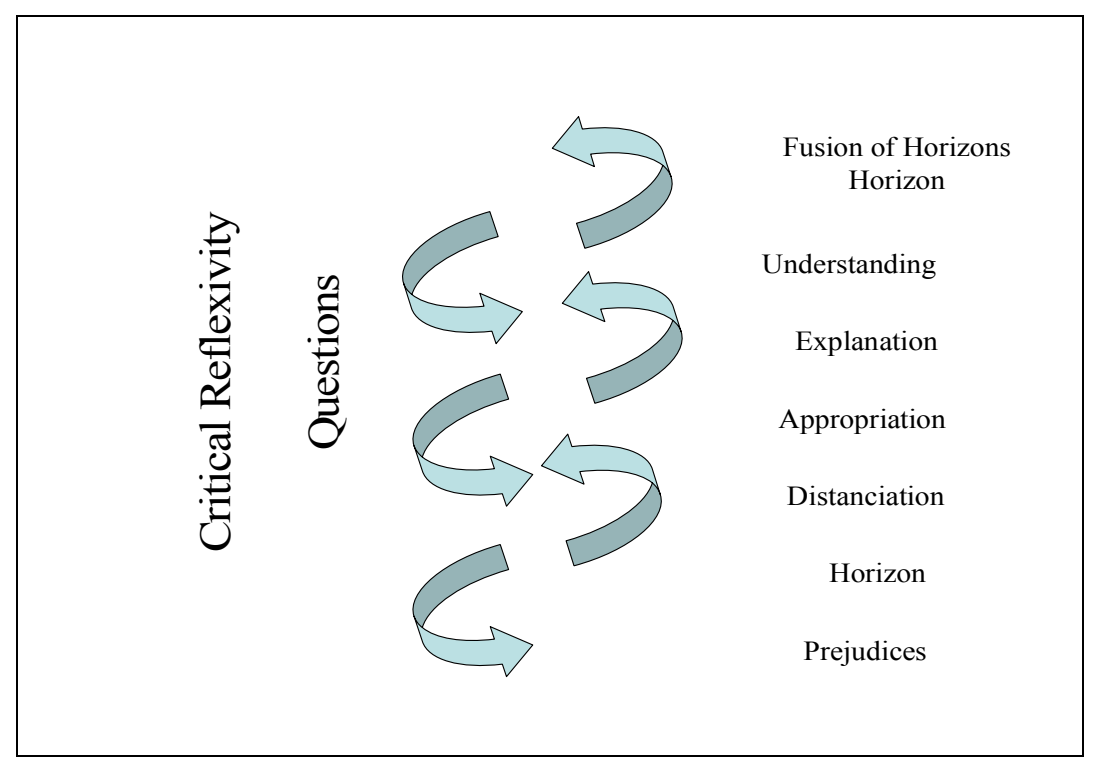

Figure 1 - Reflexive Hermeneutic Research Approach derived from Ricouer (1981) and Gadamer (1976)

In this study, it was envisioned that distanciation of the text would help ensure that during the data analysis the meaning was derived from the text and that it emerged from the conversation between the text and the researcher (Prasad 2002). This process was extended to the core of the data analysis process through the construction of additional texts, representing contexts and concepts derived from the data that informed and represented the construction of meaning (Harvey and Myer 2002). This is a recursive process that could continue indefinitely (Harvey and Myer 2002). It is the role of the interpreter to determine the appropriate moment to finalise the interpretation. This occurred when there was minimal change in interpretation and no new themes or concepts emerged from the data. Intercoder reliability was used within this study to provide confidence in the quality of the interpretation. In the words of Harvey and Myer (2002):

Every meaning is constructed, even through the very constructive act of seeking to deconstruct, and the process whereby that textual interpretation occurs must be self-critically reflected on (Ricouer 1974) (Harvey and Myer 2002, p176)

The inclusion of Ricouerís critical self-reflexivity was an important element in this research study. It encouraged the researchers to continually check and recheck the appropriateness of their analysis against the gradually evolving meanings derived from the data under analysis. The researchers sought at all times to remain critical and self-reflexive. This self-reflexivity informed the recruitment of research participants from a broad range of roles and perspectives within the organisation, it also enabled the researcher to draw concepts and questions from the IT governance 
literature to develop the interview guide, whilst still remaining conscious of the potential that exposure to the literature might impact upon their views of the interview texts.

Ricouerís concept of appropriation refers to the process of making the text oneís own (Boland 1991, Lee 1994, Geanellos 2000, Langdridge 2004). Appropriation refers to the researcher deriving meaning from the text, independently of the historical, social, cultural factors that influenced its creation, and independently of authorial intent. Ricouer saw this not as a reaching back to determine the meaning of the text but rather as a moving forward and exploring the area in front of the text and in this way challenging, shaping and altering the horizons and prejudices of the researcher (Langdridge 2004). Thus enabling the hermeneutic circle to begin again, with the researcher gaining a new understanding of herself, with which to recommence the process of understanding the meaning of the text (Geanellos 2000). In the course of this research appropriation is another mechanism that was used to challenge and expand prejudices and preconceptions, resulting as it did in a movement of the researchers own horizon.

Ricoeurís theory of interpretation is underpinned by two concepts:

1. Explanation, or what the text says; and

2. Understanding, or what the text talks about (Geanellos 2000, p114)

The explanation of the text refers to the detailed and careful analysis of the individual components of the text, while understanding the text requires the researcher to lift their focus to take in the whole meaning of the complete text (Geanellos 2000). For the hermeneutic researcher this process should be a circular and iterative one, in this way the depth of the interpretation is strengthened, moving from simple initial interpretations to deeper and more complex subsequent meanings. In this research this approach was adopted to analyse the data.

Gadamer sees the use of questions as key to enabling a valid interpretation (Butler 1998), according to Gadamer understanding is not possible without the activity of questioning (Fleming et al 2003, p117). Gadamer sees questions as a means to open possibilities and to keep them open (Butler 1998). They can also be used to offset or mediate the impact of a researcherís pre-existing prejudices. Questions can do this by assisting the researcher to remain constantly in touch with what those prejudices are and to assist with not taking anything for granted. In this research questions were used, for example, to challenge the researchers existing prejudices, to aid the identification of an appropriate participant profile and to inform and develop the research interview guide.

In addition, Gadamerís belief in the plurality of meaning was acknowledged as adding strength to Ricouerís approach that implies that one valid truth can be found (Geanellos 2000). In this research the researcher made a conscious effort to uncover, communicate and encompass the broadest possible plurality of meaning into the research study in order that both the data and the resulting findings are of the highest quality. This attempt to remain open to plurality of meaning throughout the research process manifested in the number and selection of interviewees, the selection of organisational artefacts and has been extended to the selection of research literature the researcher incorporated into the study.

Gadamer was strongly aware of the importance of acknowledging prejudices (Butler 1998) and actions and activities to highlight the researcherís prejudices have been incorporated into the research approach in order to assist the researcher to constantly challenge her initial and subsequent interpretations. This was done by:

1. Including intercoder checking into the data analysis,

2. Continually questioning conclusions and ideas that emerged from the data, 
3. Seeking participants from a broad range of roles within the organisation, so that multiple perspectives and views were discovered and as a consequence questioned and integrated, and

4. Informing the researcherís review of the existing literature and how that impacted upon the researcherís opinions and views.

Finally Gadamerís (1976) notion of horizon and the eventual fusion of horizons that occurs at the moment understanding is reached (Butler 1998) was applied in this research. Gadamer saw horizons as everything that can be seen from one particular point (Butler 1998, Fleming et al 2003). A horizon is a constantly changing phenomenon. It is suggested that a personís view is coloured and varied by their cultural background, their historical understanding of the phenomenon being viewed, and by social and traditional factors. It is through challenging and working through these preexisting impacts and prejudices that oneís horizon can move over time. The result of working toward common understandings in this way can be a fusion of horizons between individuals. When there is a fusion of horizons, there also is understanding (Butler 1998).

Having the researcher complete the data collection and transcription of all interviews and other documents for analysis within this study was a decision also based on Gadamerís hermeneutics. Gadamer believed that understanding is gained through dialogue, and that activity, such as conducting and transcribing interviews, should not be delegated as they contribute to a fuller immersion in the topic and a greater opportunity for shared understanding through dialogue between researcher and interviewee (Fleming et al 2003). This in turn should support movement toward fusion of horizons, or greater understanding between researcher and participants. It is should be noted though that in the words of Myers (1994):

The hermeneutic-dialectic approach does not accept uncritically participantsí own views on a particular topic; rather, it recognises that the researcher (or developer) attempts to critically evaluate and transform social reality, a reality that is historically constituted (p191).

At some stage the researcher must call a halt to what Gadamer believed should be an endless cycle of interpretation, reach the final understandings and record the results of the research. In pursuit of valid research outcomes and to help in establishing an endpoint to the interpretation of the data, the authors chose to employ the technique of intercoder checking. This is an additional step that introduces added rigour into the research method and relies on the use of questions, to help identify, challenge and overcome interpreter prejudices and to confirm the appropriate point in the research process to discontinue the cycles of interpretation. Thus the hermeneutic circle is closed.

\section{RESULTS OF USING THE HERMENEUTIC APPROACH}

It is important to recognise that the interpretivist epistemology adopted in this research is not one clear definable approach. Rather interpretivism is moulded and formed by the intent and application of the researcher (Schwandt 1994). For example, it is commonly acknowledged that hermeneutics is one form of interpretivism (Lee 1994). Other forms of interpretivism include postmodernism and deconstructionism (Kein and Myers 1999) Klein and Myers (1999, p70) go on to describe interpretivism as ì family of paradigms too large and diverse to tackle for this projectî. The purpose of drawing the readersí attention to the diversity of forms is to illustrate what might be described as the illusory nature of interpretivism. Illusory because the purpose of the epistemological level is to consider issues of being and knowing rather than remain focussed on the minutia of the mechanism by which knowledge or understanding is derived. However, because of 
the nature of interpretivism and the need for the researcherís epistemological intention and approach to be clear, it is important for the researcher to carefully document and record the ì process of meaning constructionî (Schwandt 1994, p118). In this research, the use of a clearly defined hermeneutic approach proved beneficial in this regard enabling the researcher to maintain a consistent philosophical position, thus ensuring the basic integrity and internal consistency of the research process.

Another major advantage of the hermeneutic approach used in this research is in its recognition and embracing of prejudice. In this research, the primary researcher spent considerable time and effort in becoming aware of her own prejudices and recognising these as the point where understanding begins (Myers 2004). This researcher became a part of the research situation. Interview data was socially constructed in the exchange between researcher and participant and again in the process of transcription and analysis. The hermeneutic approach provided recognition of this reality and a useful mechanism for raising an awareness of these prejudices such that meaning in the research became apparent (Myers 2004).

The hermeneutic approach also offered benefits in increasing the validity of the research. As indicated earlier, carefully and accurately documenting the research process is an important step in interpretivist research. In this research, the development and application of a clearly articulated hermeneutic approach supported detailed recording of the researcherís reflections throughout the research journey. Transferability refers to relevance of the research results to other settings. To facilitate transferability in this study, the research process, setting, participants (Burke Johnson 1997), and the findings were detailed in a richer, more accurate and more complete manner supported by the hermeneutic approach (Guba and Lincoln 1989, Trochim 2001). This detailed account should enable a reader of the research results to make their own decision about the appropriateness of the research findings for their situation.

Since dependability relies on the researcherís rich and detailed description of processes, methods and approaches used (Flick 2002) the writing process in this research began early to ensure higher degrees of accuracy and the writing continued thoughtfully throughout the research journey.

In addition, the conscientious application of intercoder reliability by both researchers increases dependability in this research by providing a structured opportunity for feedback and to challenge the primary researcherís evolving interpretations and analyses (Flick 2002).

The critical reflexivity demanded by the hermeneutic approach also enhanced the dependability of the research process through continually challenging the researchers to reconsider and review emerging interpretations (Flick 2002).

The rich, detailed documentation and interpretations will assist the reader to clearly follow the research decisions made and will contribute to the auditability of the process.

Applying the hermeneutic approach also supported confirmability, i.e., the extent to which others can corroborate the results of the research (Trochim 2001). This occurred through the use of:

1. Intercoder reliability during the data analysis phase,

2. Careful and detailed documentation of the process,

3. Seeking out and reviewing occurrences in the data that did not support the emerging research findings, negative cases (Burke Johnson 1997, Mays and Pope 2000). 
In addition the critical reflexivity inherent within the hermeneutic approach used offered an opportunity for continuous and productive challenging of the research process. This enabled identification of paradoxes and contradictions in interpretation, and how it evolved over the period of the research, and the subsequent documentation of the research (Mays and Pope 2000, Lincoln and Guba 2003).

The overall benefit gained in this research from the adoption of a hermeneutic approach was a more robust research framework that was synergistic with the philosophical underpinnings of the research. This enabled the researchers to move with confidence through the research process knowing that at every stage in the journey each step was designed to ensure greater immersion in the research and to enhance the richness of the data collection and analysis. Perhaps equally as important was the knowledge that any prejudices held or assumptions made would be subject to challenge, through questioning, critical self-reflexivity or the use of other techniques, such as intercoder checking.

\section{CONCLUDING REMARKS}

In exploring the most appropriate of the various qualitative research techniques for an ongoing research project in IT governance, the authors happened upon a most interesting and exciting option and were thus introduced to the intricacies of the ancient art of hermeneutics. Given the anticipated richness and rigour the application of hermeneutics promised to add to their qualitative process, the authors persevered through many difficult and complex descriptions of hermeneutics until they gained a level of comfort and confidence in its applicability and use. The comprehensive chronological discussion of its evolution and comparative discussion of the various hermeneutic approaches provide a greater understanding of the breadth and depth of hermeneutics and the distinct applicability of its various approaches to case studies in general and IS research in particular. This report on the application of one approach to hermeneutics in a case study of IT governance in a large Australian organisation is an attempt to ease the way of others who may be considering a similar choice. In addition, it illustrates the unique benefits to be gained by using hermeneutics in IS research to strengthen the dependability and validity of qualitative inquiries and hopefully promotes an increased understanding of the various approaches to hermeneutics.

IS research is uniquely poised to benefit greatly from hermeneutics as a valuable qualitative research tool. The IS research community is continually called upon to conduct inquiries into emerging phenomena. Such inquiries could benefit from robust tools that go beyond descriptive analysis to rigorously explain their impact. Hermeneutics is one such tool that will allow qualitative IS researchers to transcend the usual everyday descriptive character of qualitative understanding of these emerging phenomena to identify paradoxes and contradictions, challenge assumptions and plumb the depths of inquiry to develop strong, dependable explanatory foundations for subsequent quantitative inquiries.

In sharing the authorsí insights into the challenges of understanding, choosing and applying hermeneutics as an appropriate research philosophy and data analysis tool this paper is the first attempt to demystify the often misunderstood and overrated complexities of applying hermeneutics to IS research and is designed to encourage more widespread acceptance and application of hermeneutics within the broader IS research community. 


\section{REFERENCES}

Barley, S. R. (1986). ì Technology as an occasion for restructuring: Evidence from observations of CT scanners and the social order of radiology departmentsî. Administrative Science Quarterly, Vol 31, Iss 1, pp 78-108.

Bleicher, J. (1980). Contemporary Hermeneutics: Hermeneutics as method, philosophy and critique. Routledge \& Kegan Paul, London.

Boland Jr, R. (1985). ì Phenomenology: A Preferred Approach to Research on Information Systemsî. Research Methods in Information Systems. E. Mumford, R. Hirscheim, G. Fitzgerald and T. Wood-Harper, (Eds.)., North-Holland, New York: pp193-201.

Boland Jr, R. J. (1991). ì Information Systems Use as a Hermeneutic Processî . Information Systems Research: Contemporary Approaches \& Emergent Traditions. in H-E. Nissen, H. K. Klein and R. Hirscheim, (Eds.). North-Holland, Amsterdam: pp 439-464.

Bryman, A. (1989). Research Methods and Organization Studies, Unwin Hyman, London.

Burke Johnson, R. (1997). ì Examining the validity structure of qualitative researchî . Education 118(2): 282-292.

Bussen, W. and M. D. Myers (1997). ì Executive information systems failure: a New Zealand case studyî. Journal of Information Technology Vol 12, pp 145-153.

Butler, T. (1998). ì Towards a hermeneutic method for interpretive research in information systemsî . Journal of Information Technology Vol 13,pp 285-300.

Butler, T. (2003). ì An institutional perspective on developing and implementing intranet - and internet- based information systemsî. Information Systems Journal Vol 13, pp 209-231.

Charkham, J. P. (1995). Keeping Good Company: A Study of Corporate Governance in Five Countries. Oxford, Oxford University Press.

Demeterio, F. P. A. I. (2001). ì Dialectical Hermeneuticsî. Diwatao Vol 1, Iss 1: http://www.geocities.com/philodept/diwatao/dialectical_hermeneutics.htm, accessed 25 August 2003.

Denzin, N. K. (1970). The Research Act: A Theoretical Introduction to Sociological Methods. Chicago, Aldine Publishing Company.

Dilthey, W. (1976). ì The Rise of Hermeneuticsî . in Critical Sociology, Selected Readings. P. Connerton, (Ed.). Penguin Books Ltd, Harmondsworth.

Fleming, V., U. Gaidys, and Y Robb. (2003). ì Hermeneutic research in nursing: developing a Gadamerian - based research methodî. Nursing Inquiry Vol 10, Iss 2: pp 113-120.

Flick, U. (2002). An Introduction to Qualitative Research: Second Edition. London, Sage Publications.

Frost, P. J., L. F. Moore, M.R. Louis, C.C. Lundberg, J Martin, (Eds.) (1985). Organizational Culture. Sage, Beverly Hills, CA.

Gadamer, H.-G. (1976). ì The Historicity of Understandingî . in Critical Sociology: Selected Readings. P. Connerton, (Ed.). Penguin Books Ltd, Harmondsworth.

Geanellos, R. (2000). ì Exploring Ricoeur's hermeneutic theory of interpretation as a method of analysing research textsî. Nursing Inquiry Vol 7, pp 112-119.

Grondin, J. (1994). Introduction to Philosophical Hermeneutics. Yale University Press, New Haven.

Guba, E. G. and Y. S. Lincoln (1989). Fourth Generation Evaluation. Newbury Park, California, Sage.

Habermas, J. (1968). Knowledge \& Human Interest. Polity Press.

Hamilton, D. (1994). ì Traditions, Preferences, and Postures in Applied Qualitative Researchî in. Handbook of Qualitative Research. N. K. Denzin and Y. S. Lincoln, (Eds.), Sage Publications, Thousand Oaks. 
Harvey, L. J. and M. D. Myers, (Eds.) (2002). ì Scholarship and Practice: The Contribution of Ethnographic Research Methods to Bridging the Gapî in. Qualitative Research in Information Systems: A Reader. Sage Publications London.

Kim, C. S. and D. K. Peterson (2003). ì A Comparison of the Perceived Importance of Information Systems Development Strategies by Developers from the United States and Koreaî. Information Resources Management Journal 16(2): 1-18.

Klein, H. K. and M. D. Myers (1999). ì A set of principles for conducting and evaluating interpretive field studies in information systemsî. MIS Quarterly 23(1): 67-93.

Langdridge, D. (2004). ì The Hermeneutic Phenomenology of Paul Ricoeurî. Existential Analysis Vol 15, Iss 2, pp 243-255.

Lee, A. S. (1994). ì Electronic Mail as a Medium for Rich Communication: An Empirical Investigation Using Hermeneutic Interpretationî. MIS Quarterly Vol 18, Iss 2, pp 143-157.

Leonardo, Z. (2003). ì Interpretation and the problem of domination: Paul Ricoeur's Hermeneuticsî . Studies in Philosophy and Education, Vol 22, pp 329-350.

Lincoln, Y. S. and E. G. Guba (2003). ì Paradigmatic Controversies, Contradictions, and Emerging Confluencesî . in The Landscape of Qualitative Research: Theories and Issues. N. K. Denzin and Y. S. Lincoln, (Eds.). Thousand Oaks, Sage Publications: 253-291.

Lukaitis, S. and J. Cybulski (2004). ì A Hermeneutic Analysis of the Denver International Airport Baggage Handling Systemî. Proceedings of the Information Systems Foundations Workshop: Constructing and Criticising, Australian National University, Canberra.

Macdonald, K. and C. Tipton (1993). ì Using Documentsî. in Researching Social Life. N. Gilbert, (Ed.). London, Sage Publications: 186-200.

Mallery, J. C., R. Hurwitz, and G Duffy. (1987). ì Hermeneutics: From Textual Explication to Computer Understanding?î in The Encyclopaedia of Artificial Intelligence. S. Shapiro, (Ed.). John Wiley and Sons, New York.

Mays, N. and C. Pope (2000). ì Qualitative Research in Health Care: Assessing quality in qualitative researchî. British Medical Journal 320(7226): 50-52.

Myers, M. D. (1994). A Disaster for Everyone to See: An Interpretive Analysis of a Failed IS Project. Accounting, Management \& Information Vol 4, Iss 4, pp 185-201.

Myers, M. D. (1995). ì Dialectical Hermeneutics: A Theoretical Framework for the Implementation of Information Systemsî. Information Systems Journal Vol 5, Iss 1, pp 51-70.

Myers, M.D. (2004). ì Hermeneutics in Information Systems Researchî, in Social Theory and Philosophy for Information Systems, Mingers, J. \& Willcocks, L. Chichester, John Wiley, West Sussex. pp 103-128.

Myers, M. D. and D. Avison, (Eds.) (2002). ì Introducing Qualitative Methodsî . Qualitative Research in Information Systems: A Reader. Sage Publications London.

Olson, D. L. and J. Carlisle (2001). ì Hermeneutics in Information Systemsî. Proceedings of the Americas Conference on Information Systems, Boston, Massachusetts.

Peppard, J. (2001). ì Bridging the gap between the IS organization and the rest of the business: plotting a routeî. Info Systems Journal 11: 249-270.

Prasad, A. (2002). ì The Contest Over Meaning: Hermeneutics as an Interpretive Methodology for Understanding Textsî. Organizational Research Methods Vol 5, Iss 1, pp 12-33.

Ricoeur, P. (1981). Hermeneutics and the Human Sciences: Essays on Language, Action and Interpretation. J. B. Thompson, (Ed.). Cambridge University Press, Cambridge.

Robbins, S. S. and Stylianou, A. C. (2002), "A Study of Cultural Differences in Global Corporate Web Sites", The Journal of Computer Information Systems, Vol. 42, No. 2, pp. 3-9.

Scott-Baumann, A. (2003). ì Reconstructive Hermeneutical Philosophy: Return Ticket to the Human Conditionî. Philosophy Social Criticism Vol 29, Iss 6, pp 703-727. 
Schwandt, T. A. (1994). ì Constructivist, Interpretivist Approaches to Human Inquiryî . in Handbook of Qualitative Research. N. K. Denzin and Y. S. Lincoln, (Eds.). Thousand Oaks, Sage Publications.

Trochim, W. M. K. (2001). ì Qualitative Validityî. Research Methods Knowledge Base http://trochim.human.cornell.edu/kb/qualval.htm, accessed 2001(10 September 2001).

Wiklund, L., L. Lindholm, and U Lindstrom. (2002). ì Hermeneutics and Narration: a way to deal with qualitative dataî. Nursing Inquiry Vol 9, Iss 2, pp 114-125. 
